\title{
Subsurface Structure and Fluid Flow Analyses Using Geophysical Methods in Geothermal Manifestation Area of Paguyangan, Brebes, Central Java
}

\author{
Agus Setyawan*(1), Agnis Triahadini (1), Yayan Yuliananto (1), Yoga Aribowo(2), Dian Agus \\ Widiarso(2)
}

1. Department of Physics Faculty of Mathematics and Natural Sciences Diponegoro University, Semarang, Indonesia

2. Department of Geology Faculty of Engineering Diponegoro University, Semarang, Indonesia

\begin{abstract}
The indication of an active geothermal system is shown by the presence of surface manifestations such as the hot spring in Kedungoleng, Paguyangan, Brebes, Central Java. The temperature of the largest hot spring reaches $74^{\circ} \mathrm{C}$ and there is an assumption that this is an outflow of Mount Slamet geothermal system. Purposing to understand the subsurface structure around manifestation, DC-resistivity method had been applied. While Spontaneous Potential (SP) and Shallow Surface Temperature surveys were conducted to determine the thermal fluid flow pattern and its correlation the distribution shallow surface temperature respectively. The subsurface resistivity has been investigated using 5 points of the Schlumberger configuration with $400 \mathrm{~m}$ separation for each point. For the fluid and temperature pattern, a measurement using $15 \mathrm{~m}$ interval in 3 lines of conducting fixed electrode configuration has been carried out, along with a $75 \mathrm{~cm}$ of depth of temperature measurement around the manifestation area. The thermal fluid is assumed by the low resistivity of 0.756 to $6.91 \Omega \mathrm{m}$ and this indicates sandstone that has permeable characteristic. The fluid flows in two layers of Sandstone at more than 10 meter from surface of the first layer. The SP values, which is voltage (electrical potential) gradients along measurement lines, have a range between $-11-11 \mathrm{mV}$ and a depth interval of 13.42 $28.75 \mathrm{~m}$ and the distribution of temperature is between $24{ }^{\circ}-70^{\circ} \mathrm{C}$ at a tilting range of $46.06^{\circ}-12.60^{\circ}$. Hence it can be inferred that the thermal fluid moves in the Northwest direction and is controlled by a fault structure stretching from Northwest to Southeast.
\end{abstract}

Keywords: Paguyangan, resistivity, SP values, temperature, thermal fluid

Article History: Received Feb 3, 2016; Received in revised form July 11, 2016; Accepted August 13, 2016; Available online

How to Cite This Article: Setyawan, A., Triahadini, A., Yuliananto, Y., Aribowo, Y., and Widiarso, D.A. (2016) Subsurface Structure and Fluid Flow Analyses Using Geophysical Methods in Geothermal Manifestation Area of Paguyangan, Brebes, Central Java. Int. Journal of Renewable Energy Development, 5(3), 171-177.

http://dx.doi.org/10.14710/ijred.5.3.171-177

\section{Introduction}

The Mountain Slamet that belongs to the regencies of Banyumas, Brebes, Pekalongan and Tegal in Central Java is one of the prospective geothermal area in Indonesia (Widagdo et al., 2013). According to Sehah and Raharjo (2011), the estimation of its potential is 175 MW. Geothermal manifestations are found on its old western slope, namely Buaran and Pakujati (or recently has been called Paguyangan). The Pakujati manifestation is in the form of three hot springs with a temperature range of $69^{\circ}-70^{\circ} \mathrm{C}$.

The previous research in the area was a self- potential survey in Bantarkawung (Buaran) and Guci by the Geothermal Prospecting Team of the Volcanology Department of Indonesia in 1990 (not published). A study of the effect of geological structure in the old Mount Slamet reveals that the Paguyangan and Bantarkawung follow a pattern that crosses the Mountain from Northwest to Southwest (Widagdo et al., 2013). Based on the data from the Indonesian Ministry of Energy and Mineral Resources (ESDM), the geological condition of Paguyangan hot spring is dominated by tertiary sedimentary rock with chloride fluid in the temperature range of $51^{\circ}-72^{\circ} \mathrm{C}$. 
Citation. Setyawan, A., Triahadini, A., Yuliananto, Y., Aribowo, Y., and Widiarso, D.A (2016), Subsurface Structure and Fluid Flow Analyses Using Geophysical Methods in Geothermal Manifestation Area of Paguyangan, Brebes, Central Java. Int. Journal of Renewable Energy Development, 5(3), 171-177, doi: 10.14710/ijred.5.3.171-177

$\mathrm{P}$ a g e 172

Chloride fluid indicates that this hot spring is a high temperature geothermal system. However, a research by Iswahyudi et al (2013) shows that the fluid type there is bicarbonate, which indicates that it is an outflow zone resulting from the interaction of volcanic activities and the geological structure that controls it. Originally, the geothermal prospect near the summit sofataras of Mount Slamet is explored Volcanology Department and Pertamina (Indonesian energy company) by employing several geophysical methods. But, there is a high volcanic risk attached of the prospect (Hochstein and Sudarman, 2008). Thus, the fact this Paguyangan manifestation has high temperature although it is located more than $30 \mathrm{~km}$ from the upflow zone of Mount Slamet is interesting to be understood about the geothermal prospectus.

The other geophysical methods are required to study the geological structure and geothermal system in Paguyangan as the number of such studies are still limited in the area. Thus, we utilized some geophysical methods, they are DC-resistivity, Spontaneous Potential (SP), and shallow surface temperature. The DCresistivity method in this research utilized the one dimensional Schlumberger configuration. The SP configuration used is the fixed electrode configuration. This research is aimed to determine the pattern of fluid flow and shallow surface temperature distribution in Paguyangan geothermal system, and identifying the rock layers that serve as permeable layer and control structure for the manifestations observed as well.

\section{Geophysical Methods Overview}

The three geophysical method we used are common methods for geothermal preliminary survey. The Spontaneous potential (SP) method has been widely recognized to investigate subsurface hydrology and high-temperature geothermal resources, but only for limited condition low-to-intermediate temperature system. In geothermal exploration, the fluid flow pattern is based on electrokinetic process mechanism where an electrolyte fluid flowing in porous media are experiencing separation and accumulation of electric charge. the presence of water or fluid movement in beds can lead to SP phenomenon. The vertical movement of fluid that seeps generate positive value of SP can lead to greater self-potential change for the greater distance. The movement of fluid vertically raises SP positive, while the horizontal movement of water can pose a greater SP to change the distance increases (Singarimbun et al., 2012). Moreover, this method is a passive electrical method which measures natural electrical current present in the ground (Mauri et al., 2012). It is simple, inexpensive and be able to detect anomaly related to geothermal field (Hase et al., 2003; Ross and Witcher, 1998) The responses from SP method has a wide variety amplitudes, shapes, multiple anomalies and may be positive or negative in polarity (Cited from Corwin and Hoover, 1979; Ross et al., 1991 in Ross and Witcher 1998).
Spontaneous potential profile often has a negative correlation to topographic elevation. This feature is typically obvious in a mountainous area and on the flanks of volcanoes, and sometimes called a "topographic effect" on SP. This is widely believed to arise from the streaming potential due to the potential flow of groundwater from higher to lower elevations. The positive SP anomalies versus altitude in the central part of volcanoes (the summits) are usually interpreted upward flows or large-scale of hydrothermal circulation(Sasai et al., 2002; Hase et al., 2003). According to Corwin and Hoover (1979), the positive anomalies can be seen over faults which are thought toact as a conduit for thermal fluid.

The field data is made in the coordinates (longitude and latitude) form. The measured data is corrected with base point (reference) and elevation. Making contour map of SP values can be obtained by gridding data process in Surfer 11 software after correcting raw data field. Basically, each grid value is based on the interpolation model. The known data points neighboring the node while each data point is weighted by its distance away from the node (Singarimbun et al., 2012, Aizawa, 2008).

Shallow temperature survey at a depth of 1-meter or lesser is aimed for mapping thermal anomalies with a high level of detail. These thermal anomalies can be associated with interesting geothermal features. However, variations in near-surface temperatures could be affected by some factors, including changes in air temperature, soil moisture, lithology and near-surface groundwater flow and thermal inertia (Lira et al.,2011; Olmsted and Ingebritsen, 1986). Usually, a place at greater altitudes tend to be cooler of the temperature than the sites at lower altitudes. It would be difficult to identify the altitude effect in the data because some of the other factors are related to altitude. For example, greater altitudes tend to be associated with greater depths to the water table and also with lower because of the intrution (Olmsted and Ingebritsen, 1986).

In purpose to identify conductive zones, geological structure or fluid flow pattern, the 1D resistivity method can be choosen (Mariyaningsih and Setyawan, 2014; Verave et al., 2015). It can invesitgate target deeper than 2D resistivity and can recognize geological structure based on the contrast in resistivity values. Rocks type identification occurs by matching the true resistivity values (generated from data processing) with the geological information (Broto and Afifah, 2008). Rock in the natural surroundings of high temperature geothermal systems are generally affected by hydrothermal alteration that changes the resistivity of the rock. These changes can be detected by resistivity method, the subsurface resistivity distribution can tell about the parameters directly influencing the geothermal system.

Low resistivity indicates the existence of conductive zones, reservoar or special structure 
Citation. Setyawan, A., Triahadini, A., Yuliananto, Y., Aribowo, Y., and Widiarso, D.A (2016), Subsurface Structure and Fluid Flow Analyses Using Geophysical Methods in Geothermal Manifestation Area of Paguyangan, Brebes, Central Java. Int. Journal of Renewable Energy Development, 5(3), 171-177, doi: 10.14710/ijred.5.3.171-177

P a g e 173

(Sundoro et al., 2006; Verave et al., 2015). Verave et al (2015) observed Talasea geothermal Field in Papua New Genea and found that there is a very low resistivity at shallow depth at manifestation area which also can be linked to conductive zone of geothermal system with temperatures of $50^{0}-200^{\circ} \mathrm{C}$. This method works properly to estimate vertical variation of resistivity at shallow depth of less than $1 \mathrm{~km}$ (Suparno et al., 2010).

\section{Geological Characteristic of the Research Area}

The island of Java is physiographically and structurally divided into four main parts: western Cirebon (West Java), Central Java (Cirebon to Semarang, East Java (Semarang to Surabaya), and the East of Java island; Madura strait and Madura island (100-120 km long from North to South). Central Java is made of two mountain ranges; the North Serayu Mountains that borders with the Bogor Mountain Range in the West, and the Kendeng Mountain Range in the East, and the South Serayu Mountains that is a continuation of the Bandung Depression in West Java. The North Serayu Mountain has an area of $30-50 \mathrm{~km}$. And its western side is bordered by Mount Slamet, whereas its eastern side is covered by the young volcanic mountain sediment of Mount Rogojembangan, Mount Prahu, and Mount Ungaran (Bemmelen, 1949 in Widagdo 2013).

Mount Slamet is the highest volcanic mountain in Central Java. It is best divided into two main morphological groups; the Old Mount Slamet that comprises its western slope, and the Young Mount Slamet that resides on its eastern side (Widagdo, 2013). According to Djuri et al (1996), the rocks on the slopes of Mount Slamet are comprised of breccia, lava, and tuft (Qvs) for the Old Mount Slamet, while the Young Mount Slamet is made of breccia and lava (Qvs), then lahar breccia (Qls) is found in both Young and Old Mount Slamet.

\section{1) Geographical Location Paguyangan}

Paguyangan geothermal area is geographically located at 109o 24' 31.98" BT - 109o 0' 42.81" BT and 7o $19^{\prime} 25.94^{\prime \prime}$ LS - 7o 19' 15.03" LS. It is administratively within the area of Brebes regency, and is $48 \mathrm{~km}$ away from its capital.

\section{2) Stratigraphy}

The research location is around the Paguyangan geothermal manifestation area, which is dominated by sedimentary rocks from the tertiary era. The data measurement points are $80 \%$ located in the tertiary sediment rocks; namely the rambatan formation (Tmr) and the rest are on the lava sediment of Mount Slamet (Qls). Some rocks that make up both the old and young formation (Fig. 1) in the research area are Rambatan formation (Tmr), Halang formation (Tmph and Tmh), Tapak formation (Tpt), and Lahar sediment of Mount Slamet (Qls). Rambatan formation (Tmr) consists of sedimentary rocks; shale, clay (marl), and calcareous sandstone. Thin layer of perpendicular calcite to sedimentation plane are also found. Fossilized foraminifera is also common. This formation has a thickness of $300 \mathrm{~m}$. The sedimentation of this formation has started since the mid-Miocene period.

The Halang formation (Tmph and Tmh) consists of sandstones with fragments of andesite, conglomerate, tuff, and clay. Halang formation was formed from the end of Miocene to Pliocene with a thickness of $800 \mathrm{~m}$. On top of this sandstone layer are remnants of worms. These small foraminifera indicate that the adjacent layer is from the end of Miocene to Pliocene. This layering of rocks forms an anticline that makes up the morphology reversion, in which the axis of anticline is at the lower elevation and is directly joined by a thrust fault (Putrohari, 2013).

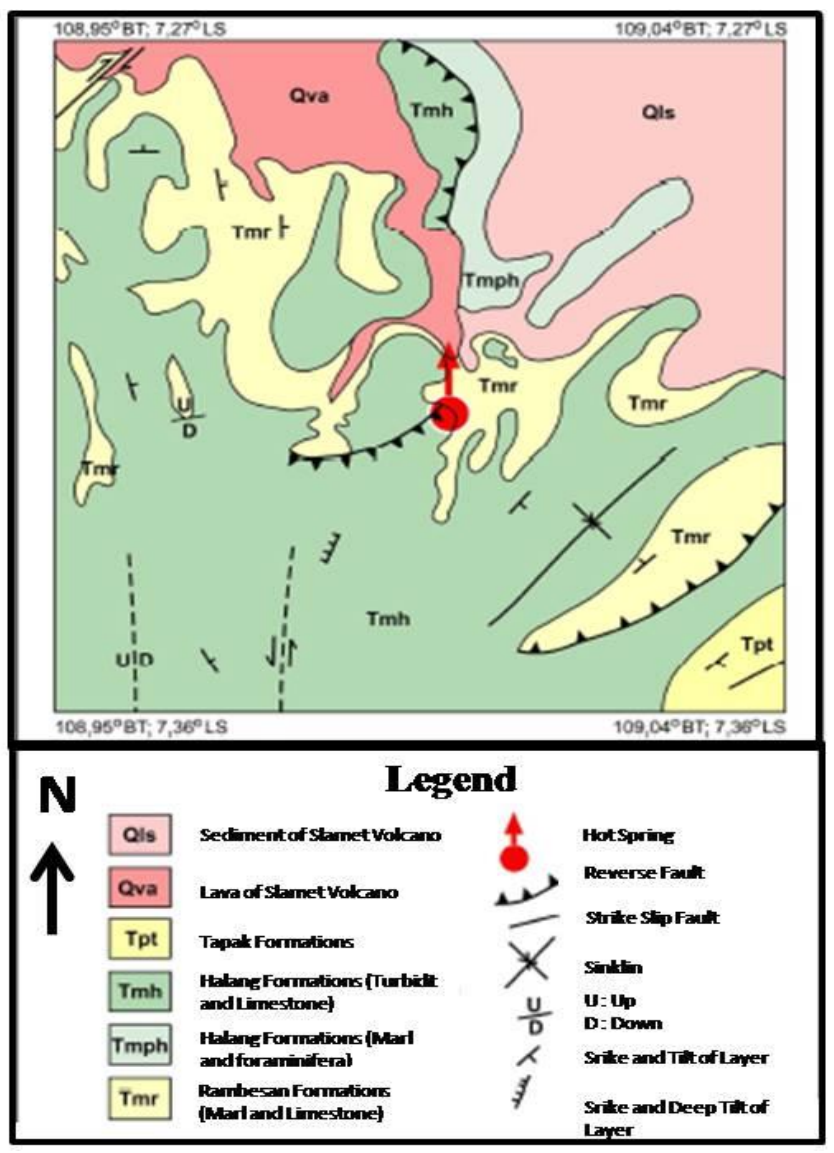

Fig 1. Regional geology map of the research area (excerpted from Djuri et al., 1996, and Kastowo, 1975 in Iswahyudi et al., 2013).

The Tapak formation (Tpt) consists of greenish rough sandstone, conglomerate, and local andesite breccia. On the top, there is a layer of limy sandstone and greenish clay with fossils of mollusks in it. It has a thickness of $500 \mathrm{~m}$. The lahar sediment of Mount Slamet (Qls) is made of volcanic rocks, comprises of andesitebasalt, with diameters of 10-50 cm, from the Old Mount Slamet. They are distributed in the flat terrains (Djuri et al., 1996), whereas the volcanic product of the Old Mount Slamet sediment (Qva) consists of lahar deposit 
Citation. Setyawan, A., Triahadini, A., Yuliananto, Y., Aribowo, Y., and Widiarso, D.A (2016), Subsurface Structure and Fluid Flow Analyses Using Geophysical Methods in Geothermal Manifestation Area of Paguyangan, Brebes, Central Java. Int. Journal of Renewable Energy Development, 5(3), 171-177, doi: 10.14710/ijred.5.3.171-177

$\mathrm{P}$ a g e 174

from Mount Slamet and lava layers underneath it in some areas. This formation creates a relatively flat topography with sharp edges along the rivers (Iswahyudi et al., 2013)

\section{3) Geological Structure}

Hot springs as geothermal manifestations are found in the research area. The three hot springs there have temperatures ranging from $\left(74^{\circ} \mathrm{C}\right.$ to $\left.72^{\circ} \mathrm{C}\right)$. They are in one line and are separated by a distance of $\pm 10 \mathrm{~m}$ from each other. This straight line of manifestation indicates the existence of a fault.

The research area is surrounded by some uncovered geological structures. Surface geological appearance includes hills and rivers along with their creeks. Its geological structure in detail includes strike slip fault, normal fault, thrust fault, and syncline (Fig. 1). This type of geological structure is normally found in the tertiary formation such as Rambatan formation (Tmr), Halang formation (Tmph and Tmh), and Tapak formation (Tpt). Strike Slip Fault occurs at the sediment resulting from the deposit of lahar and lava of Mount Slamet (Qva). Fracture is observable in the contour adjustment patters on the map. This fracture stretches from the oldest rock, Rambatan formation, to the youngest rock, lahar sediment of Mount Slamet (Qls) (Fig. 1).

\section{Research Methodology}

Data measurement was conducted on 3-4 May 2014 in the hot springs manifestation area at Desa Kedungoleng, Paguyangan sub district, Brebes regency. Details of points are listed in Table 1 . The Naniura type NRD 22S Resistivitymeter was used to measure data, whereas the configuration used was the Schlumberger configuration with 5 sounding points with a maximum space for current electrodes (AB) at $400 \mathrm{~m}$.

Table 1.

Sounding points

\begin{tabular}{|ccc|}
\hline Sounding Point & Latitude (UTM) & Longitude (UTM) \\
\hline 1 & 9190407.37 & 280125.35 \\
2 & 9189919.86 & 279667.35 \\
3 & 9290036.46 & 280323.34 \\
4 & 9190778.00 & 280332.00 \\
5 & 9190861.70 & 282350.10 \\
\hline
\end{tabular}

Source :Survey data

The method used for spontaneous potential data acquisition is fixed electode. This method places an electrode at a certain point as a tier, while the other electrodes are moved to certain other points along the measurement route. In this research, the first fifteen point intervals are used as the tier. It means to calibrate the other points. On the other hand, surface temperature is measured at $75 \mathrm{~cm}$ deep, with a $15 \mathrm{~cm}$ space between each measurement point.

\section{Result and Discussion}

\subsection{Analysis of Resistivity Line Section}

For making subsurface analysis, two points of measurements that possibly cross geological structure should be connected based on resistivity value and thickness of each layer. The subsurface section is made by connecting points 1 and 3 and later it is called line I. The result of rock type can be seen in Table 2. Points 2 and 3 are connected to make line II then points 1 and 4 are connected to make line III. Sounding point 5 is not included in interpretation as its location is at a different rock formation.

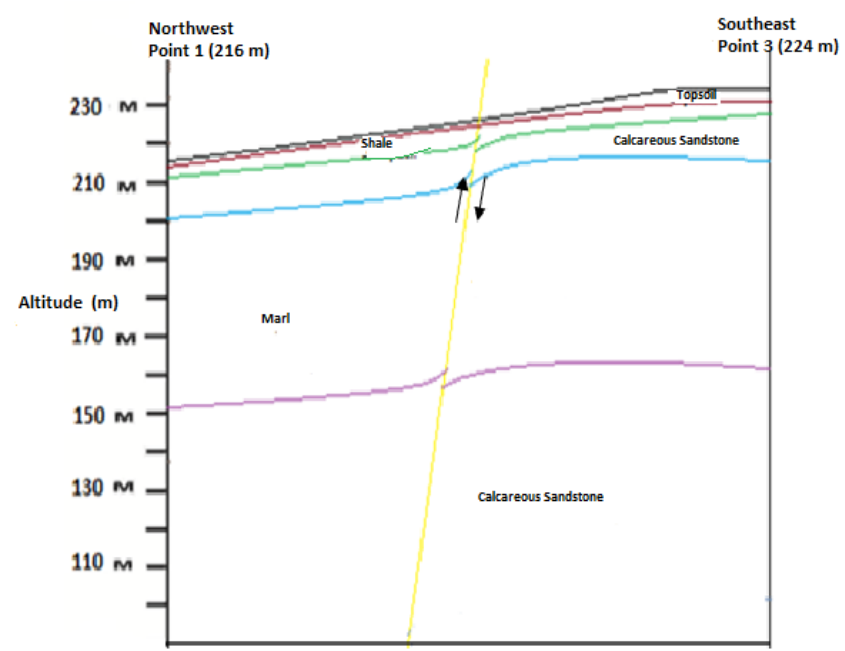

Fig 2. Model of subsurface section of line I with y-axis is the altitude from the sea level

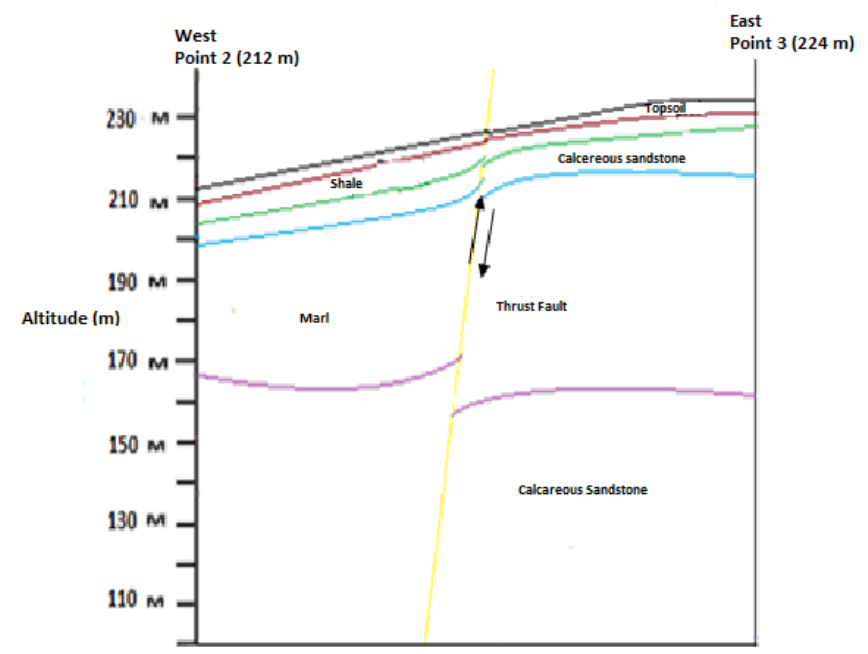

Fig 3. Model of subsurface section of line II. with y-axis is the altitude from the sea level.

Table 2.

Subsurface lithology composition.

\begin{tabular}{ccc}
\hline Layer & $\boldsymbol{\rho} \mathbf{( \Omega \mathbf { m } )}$ & Lithology \\
\hline 1 & $9,91-114$ & Topsoil \\
2 & $45,1-107$ & Shale \\
3 & $1,58-4,26$ & Calcareous Sandstone \\
4 & $34-92,3$ & Marl \\
5 & $1,28-6,91$ & Calcareous Sandstone \\
\hline
\end{tabular}

Source: Data processing 
Citation. Setyawan, A., Triahadini, A., Yuliananto, Y., Aribowo, Y., and Widiarso, D.A (2016), Subsurface Structure and Fluid Flow Analyses Using Geophysical Methods in Geothermal Manifestation Area of Paguyangan, Brebes, Central Java. Int. Journal of Renewable Energy Development, 5(3), 171-177, doi: 10.14710/ijred.5.3.171-177

$\mathrm{P}$ a g e 175

As the estimation, the three lines (I, II, and III) consist of five layers; top soil, shale, calcareous sandstone, clay, and calcareous sandstone. Calcareous Sandstone has sufficient permeability to pass the water through. This is confirmed by the low resistivity observed, compared to the other layers, which indicates the presence of fluid in its pores.

This same estimation has been observed by Azwar (2009) on modelling of permeable layers using resistivity values data. Moreover, sandstone is the most common rock that serves as a reservoir (around 60\% reservoirs in the world), related to its permeability. Sandstone is compact yet loose naturally (Nurwidiyanto et al., 2006). The thrust fault identified in line I and II is determined to serve as control for the manifestation. Geological information of the area also confirms this presence of a thrust fault.

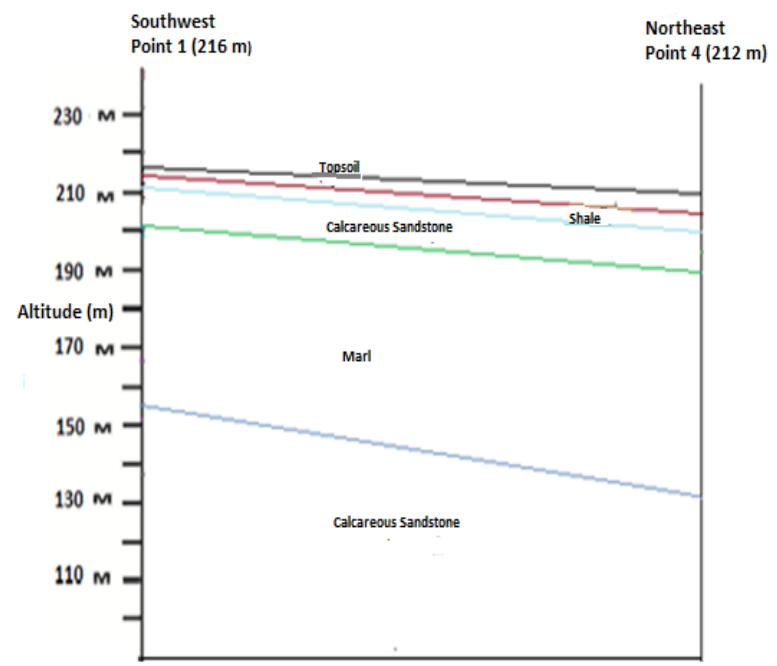

Fig 4. Model of subsurface section of line III with y-axis is the altitude from the sea level.

\subsection{Analysis of Self-Potential Values and Temperature's Distribution}

Daily and topographic corrections were applied to those raw data (SP data). The corrected data were processed using Surfer 11. The result was a contour map of spontaneous potential distribution. Then further processing to make a profile graph of spontaneous potential values, we took into account the cross-section taken from the spontaneous potential contour map and the shallow surface temperature distribution at $75 \mathrm{~cm}$ depth. The shallow surface temperature measurements were carried out at $15 \mathrm{~cm}$ interval (3 lines). We measured temperature data randomly in purpose to make the distribution denser. Shallow surface temperature relates to altitude in the higher place, the lower the shallow surface temperature is. Line 2 and line 3 are on the same altitude, but their temperatures are different due to their location relative to the heat source. The closer a location to a heat source, the higher the temperature is.
The shallow surface temperature ranges from $24^{\circ} \mathrm{C}$ to $70^{\circ} \mathrm{C}$. In line 1 there is a high anomaly at $70^{\circ} \mathrm{C}$. In line 2 and 3, there are no high temperature anomalies. The temperature tend to be low because of their distance to the heat source and the temperature generally lower if the ground is higher. The spontaneous potential anomaly observable in the area shows the presence of thermoelectric effect via thermal conduction. Values in lines 1 and 2 are around a few tens of $\mathrm{mV}$, either positive or negative, with average height of $220 \mathrm{~m}$ to $238 \mathrm{~m}$, as depicted in Fig. 5. Thermal conduction causes an increase in spontaneous potential anomaly distributed evenly in the area and it affects local flow of potential.

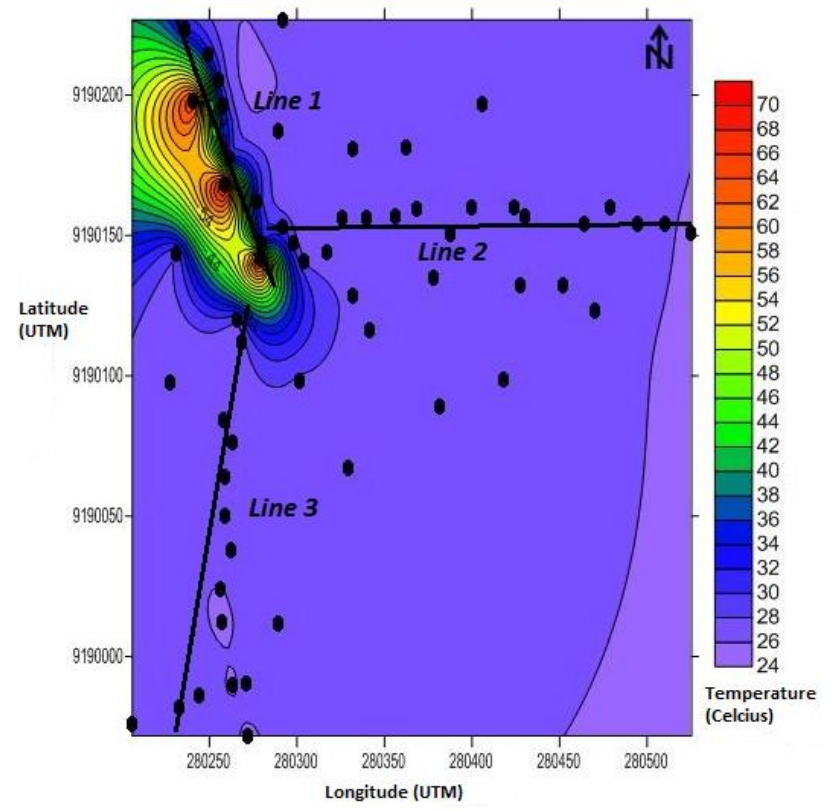

(a)

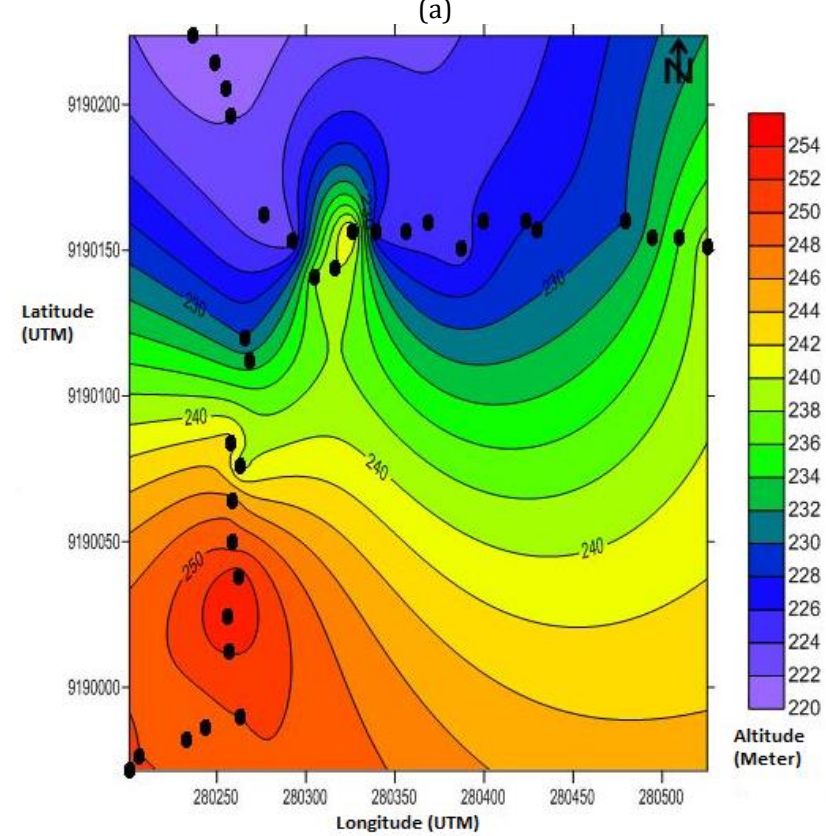

(b)

Fig 5 (a) Contour map of temperature distribution at a depth of $75 \mathrm{~cm}$, (b) contour map of topography. 
Citation. Setyawan, A., Triahadini, A., Yuliananto, Y., Aribowo, Y., and Widiarso, D.A (2016), Subsurface Structure and Fluid Flow Analyses Using Geophysical Methods in Geothermal Manifestation Area of Paguyangan, Brebes, Central Java. Int. Journal of Renewable Energy Development, 5(3), 171-177, doi: 10.14710/ijred.5.3.171-177

$\mathrm{P}$ a g e 176

Regarding to the thermoelectric effect which states that an area given conduction current will show a value of positive spontaneous potential anomaly. The topographic effect related to fluid flow from higher to lower area is depicted in line 3.

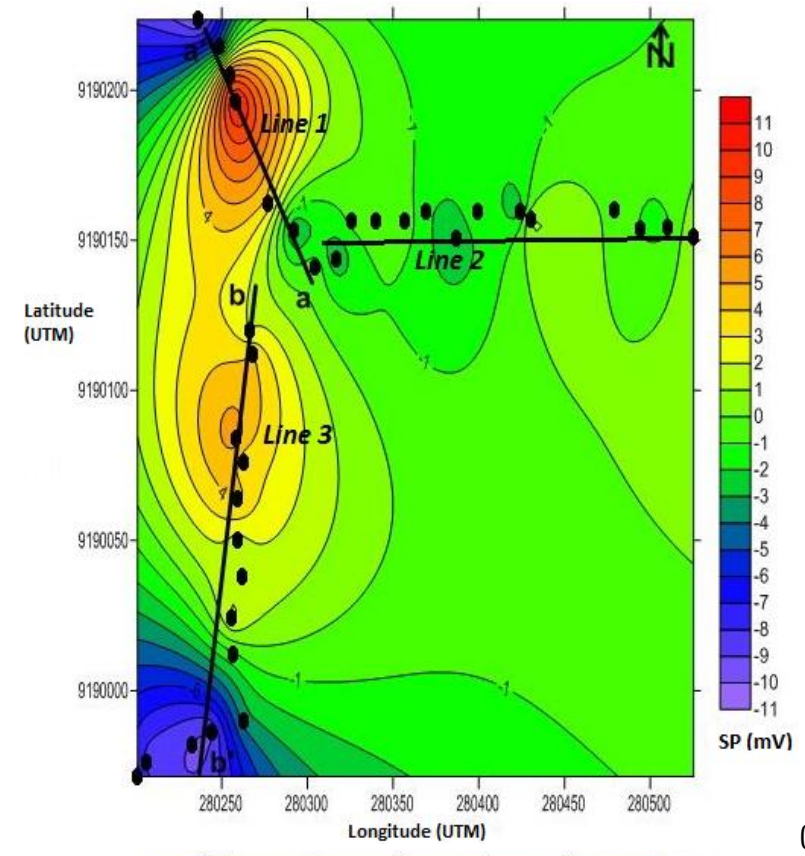

(a)

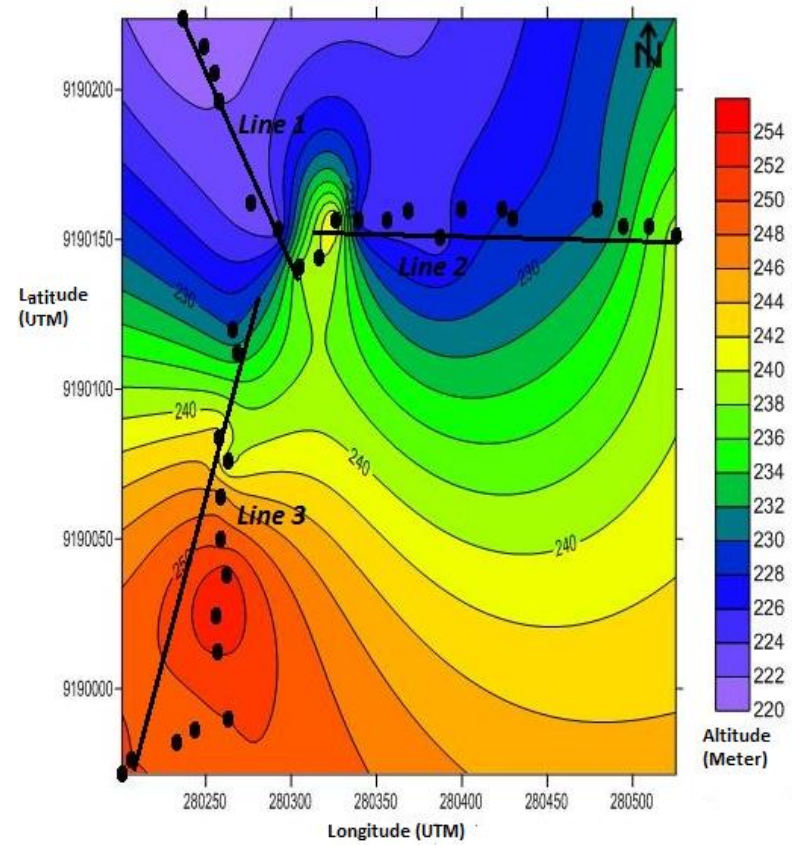

(b)

Fig 6. (a) Contour map of spontaneous potential distribution; the dots $(\bullet)$ are points of spontaneous potential distribution, (b) contour map of topography of research area.

Topographic effect explains how fluid flows from higher to lower area. This also represents the flow of the thermal fluid is from Line 2 to Line 1 in the southeastnorthwest direction, while the flow from line 3 to line 1 shows the flow pattern caused by topography factor. The depth of anomalous body from the calculation for spontaneous potential anomaly curve on line a-a' yields a top limit depth $(h)$ of $13.42 \mathrm{~m}$, and a bottom limit depth $(H)$ of $28.76 \mathrm{~m}$. And the slope on this line a-a' is $46.06^{\circ}$ against the horizontal plane. In line $b-b^{\prime}$, the top limit depth $(h)$ is $8.21 \mathrm{~m}$, whereas the bottom limit depth $(H)$ is $30.33 \mathrm{~m}$, and the slope is at $12.6^{\circ}$ against the horizontal plane. Those values of depth and slope indicate that the depth increases from slice b-b' to a-a'.

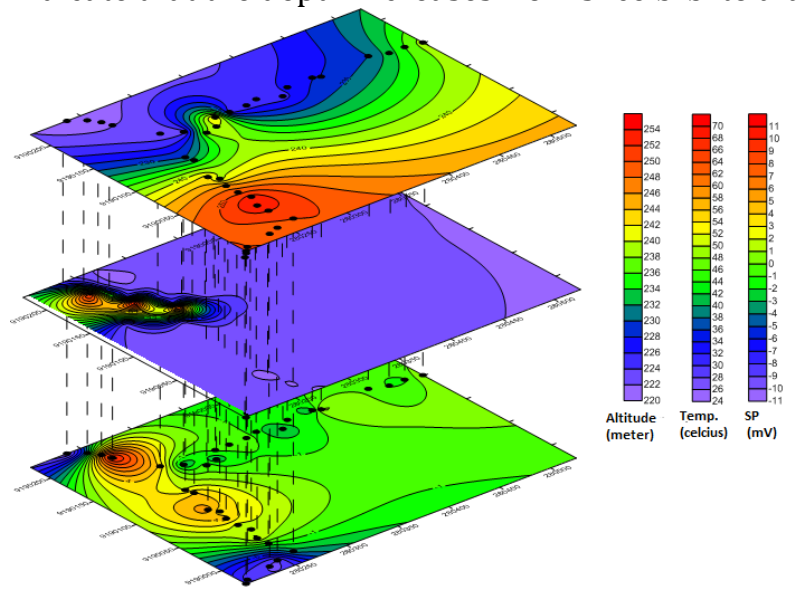

Fig 7. An overlay of contour map of height and contour map of spontaneous potential against contour map of shallow surface temperature.

The thermal fluid flows to northwest as indicated by the arrows. There is a weakened zone on the marl layer in the fault passed by the thermal fluid. This is represented as the high permeability rock layer based on the value of depth and slope of the subsurface anomalous body.

\section{Conclusion}

Based on the purpose of this study, the followings can be inferred that the structure causing geothermal manifestation on the surface is a thrust fault. The identified lithology of the research area consists of topsoil with 9.91-114 $\Omega \mathrm{m}$ resistivity value, calcareous sandstone with $0.756-6.91 \Omega \mathrm{m}$ resistivity value, and marl with resistivity value of $31-92.3 \Omega \mathrm{m}$. The repetition of sedimentation process causes layering in calcareous sandstone and marl while the calcareous sandstone has a role as a permeable layer that helps fluid escape. Moreover, shallow temperature surface distribution occurs at altitude of $215 \mathrm{~m}$ to $265 \mathrm{~m}$ with ranges of temperatures from $24^{\circ} \mathrm{C}$ to $70^{\circ} \mathrm{C}$. Spontaneous potential distribution for line 1 is around -10.3 to 10.6 $\mathrm{mV}$; for line 2 it is around -3.2 to $1.2 \mathrm{mV}$; and for line 3 it is around -9.1 to $5.6 \mathrm{mV}$ depending on altitude and distance from the heat source. While spontaneous potential anomaly is around -11 to $11 \mathrm{mV}$ and this shows a flow pattern from southeast to northwest. The depth ranges are $13.42-28.75 \mathrm{~m}$, and $8.21-30.33 \mathrm{~m}$, with a slope of $46.06^{\circ}-12.6^{\circ}$. This explains the presence of sandstone at a depth of more than $10 \mathrm{~m}$ from the surface. 
Citation. Setyawan, A., Triahadini, A., Yuliananto, Y., Aribowo, Y., and Widiarso, D.A (2016), Subsurface Structure and Fluid Flow Analyses Using Geophysical Methods in Geothermal Manifestation Area of Paguyangan, Brebes, Central Java. Int. Journal of Renewable Energy Development, 5(3), 171-177, doi: 10.14710/ijred.5.3.171-177

P a g e 177

\section{Acknowledgments}

The authors especially thank to the Department of Physics Diponegoro University's students including the other supporting team for helping field data measurement and also Laboratory of Geophysics Diponegoro University which equiped us the measurement tools. We greatefuly appreciate all lecturers and staff of Diponegoro University who coassisted us in result discussion and analyses as well as officers of Paguyangan Hot Spring Recreation and Paguyangan's native people for allowing us to conduct research.

\section{References}

Aizawa, K. (2008). Classification of Self-Potential Anomalies on Volcanoes and Possible Interpretations for Their Subsurface Structure. Journal of Volcanology and Geothermal Research, 175(3), 253-268

Azwar, H. (2009). Pemodelan Lapisan Air Tanah Dalam (Akuifer) di Desa Tegalrojo Kab. Demak Berdasarkan Data Tahanan Jenis. Undergarduate thesis, Islamic State University Syarif Hidayatullah, Jakarta.

Broto,S. dan Afifah,R.S,. (2008). Pengolahan Data Geolistrik Dengan Metode Schlumberger. Journal of TEKNIK, 29 (2), 120-128.

Corwin, R.F. and D.B. Hoover. (1979). The Self-Potential Method In Geothermal Exploration. Journal of Geophysics,44, 226-245

Djuri M.H, Samodra T.C, Amin S., and Gafoer. (1996). Peta Geologi Lembar Purwokerto dan Tegal Skala 1:100,000. Geological Map of Purwokerto and Tegal in 1:100,000 scale, Center of Geological Research and Development Bandung.

Hase, H., T. Ishido, S. Takakura, T. Hashimoto, K. Sato, and Y. Tanaka (2003). Z Potential Measurement Of Volcanic Rocks From Aso Caldera. Journals of Geophysical Research Letters, 30(23) .

Hochstein, M.P and S. Sudarman. (2008) History of geothermal Exploration in Indonesia from 1970 to 2000. Journal of Geothermics, 37, 220-266.

Iswahyudi S, Widagdo A, Subana, and Herdianita N.R. (2013) Outflow Zone Indication of Geothermal System in Paguyangan Hotspring Brebes, Central Java, Proceeding of $2^{\text {nd }}$ Geothermal Workshop ITB Bandung.

Lira, E., R.Arcos, J.Clavero, A. Giavelli and C. Mayorga (undated). Shallow Temperature Measurements at Juncalito, A Geothermal prospect, Central Andes, Chile, Article at http://biblioserver.sernageomin.cl/opac/DataFiles/14127 pp 6 18 620.pdf., Accessed on 26 June 2015.

Mariyaningsih, D dan Setyawan, A. (2014). Interpretasi Struktur Bawahpermukaan Menggunakan Metode Geolistrik Konfigurasi Schlumberger di Area Manifestasi Panasbumi Kaliulo, Gunung Ungaran. Journals of Youngster Phyisics Journal, 2(1), 25-30.

Mauri, G., Williams-Jones, G., Saracco, G., and Zurek, J.M. (2012). A Geochemical and Geophysical Investigation of Hydrothermal
Complex of Masaya Volcano, Nicaragua. Journal of Volcanology and Geothermal Research, 227-228.

Nurwidiyanto, M.I., Yustian, M., and Widada, S. (2006). Pengaruh Ukuran Butir Terhadap Porositas dan Permeabilitas pada Batupasir (Studi Kasus: Formasi Ngrayong, Kerek, Ledok Dan Selorejo), Semarang. Journal of Berkala Fisika Diponegoro University, 9(4), 191-195.

Olmsted, F.H. and S.E. Ingebritsen. (1986). Shallow Subsurface Temperature Surveys in The Basin And Range Province-II. Ground Teperatures In The Upsal Hogback Geothermal Area, West- Central Nevada, U.S.A. Journal of Geothermics, 15 (3), 267-275, Pergamin Journals.

Putrohari, R.D. (2013). Evaluasi Ringkas Geologi Waduk Penjalin. Appendix 2, Press Release IAGI Pebruary.

Ross, H.P. and J.C. Witcher. (1998). Self-Potential Surveys Of Three Geothermal Areas in The Southern Rio Grande Rift, New Mexico. Paper of New mexico geological society fall field conference guidebook.

Sasai, Y., M. Uyeshima, J. Zlotnicki, H. Utada, T. Kagiyama, T. Hashimoto and Y. Takahashi. (2002). Magnetic And Electric Field Observations During The 2000 Activity Of Miyake-Jima Volcano, Central Japan. Journal of Earth and Planetary Science Letters, 203, 769-777.

Sehah and Raharjo, S.A. (2011). Survei Metode Self Potential Menggunakan Elektroda Pot Berpori Untuk Mendeteksi Aliran Fluida Panas Bawahpermukaan di Kawasan Baturaden Kabupaten Banyumas Jawa Tengah, Purwokerto. Journal of Fisika FLUX, 8 (1): 7-11.

Singarimbun, A., Djamal, M. and Meilawati, F. (2012). Fluid Flow Direction Beneath Geothermal Area Based on Self-Potential Data (A Case Study at Mount Patuha, West Java, Indonesia. International Journal of Geology , 6(1).

Suparno, S., Y. Daud, S. Rosid, D. Djuhana and Y. Sofyan. (2010). New Interpretation Of DC Resistivity Data In The Sibayak Geothermal Field, Indonesia. Proceeding of World Geothermal Congress.

Sundhoro, H.,Bakrun, B. Sulaeman, T. Situmorang, D. Risdianto and E. Sumardi. (2006). Reservoar dan Model Panas Bumi di G. Puma, Kabupaten Dompu, P. Sumbawa Berdasarkan Karakter Geologi, Geokimia dan Geofisika. Article of Buletin Sumber Daya Geologi, $1(3)$.

Widagdo, A., Candra, A., Iswahyudi, S., and Abdullah, C.I. (2013). Pengaruh Struktur Geologi Gunung Slamet Muda dan Tua Terhadap Pola Sebaran Panasbumi. Proceeding of $4^{\text {th }}$ Industrial Research Workshop and National Seminar Bandung State Polytechnic.

Verave, R.T., N. Mosusu and P. Irarue. (2015). 1D Interpretation of Schlumberger DC Resistivity Data from the Talasea Geothermal Field, West New Britain Province, Papua New Guinea. Proceedings of World Geothermal Congress. 